\title{
Alpine treasures - Austrian endemic arachnids in Gesäuse National Park
}

\section{Christian Komposch}

Keywords: endemism, biodiversity, conservation, protection measures, climate warming, glaciation, Eastern Alps, Austria, Gesäuse National Park, spiders, harvestmen, Araneae, Opiliones, Arachnida

\section{Abstract}

This paper deals with species whose range lies entirely (endemics) or predominantly (subendemics) within the political borders of Austria. The evolution and current distribution of Alpine endemics find their chief cause in the advent of the Pleistocene ice-ages, the destruction of much of the former fauna and in different forms of survival as well as migration from southern refugia. A first overview of endemic and subendemic arachnids of Austria shows 11 harvestman and 46 spider species. One hotspot of arachnological endemisms in the Eastern Alps are the north-eastern Calcareous Alps.

The Gesäuse National Park, an exceptional area situated in the Ennstaler Alps (Styria, Austria), contains 6 subendemic harvestman and 12 endemic and subendemic spider species, i.e. $55 \%$ and $26 \%$ of the Austrian (subendemic) spectrum. Most of these Opiliones are soil-dwelling forms, most Araneae belong to the linyphiid genera Lepthyphantes s. I. and Troglohyphantes. All these species occur from the nival down to the montane zone, and prefer rock habitats, caves, avalanche corridors and natural woodlands. $100 \%$ of these harvestman and $57 \%$ of these spider species are Critically Endangered up to Vulnerable. So far, there is no legal protection for them. A main threat to those ice-age relicts is climate warming.

There is a great need for conservation action on these endemics and for political support for the national park. Intensive basic research is required as well as encouragement for invertebrate specialists, the protection of endemics enshrined in law, conservation programmes and the creation of protected areas based on endemism hotspots, accompanied by public relations activities about these zoological treasures.
Profile

Protected area

Gesäuse National Park

Mountain range

Alps

Country

Austria

\section{Introduction}

“... daß bei intensiver Sammeltätigkeit durch Abräumen von Schutthalden, Untersuchung von Höhlen und Felsklïften, noch weitere für das Gebiet und wahrscheinlich darüber hinaus für die Wissenschaft neue Arten entdeckt werden können"

Franz \& Gunhold (1954: 461), arachnological and entomological explorer of the Gesäuse in the 1940s, describing the urgent need for further research in the north-eastern Alps.

Endemic species are the most interesting topic of faunistics and biogeography, a national contribution to global biodiversity and the biological treasure of any country. Yet, regrettably, in recent decades most federal conservation departments and national parks have ignored the occurrence of endemics in the Alps and their need for protection.

This paper aims to document this paradoxical situation and to show the urgent need for protection of endemics. It does this by presenting the exceptional conservation work done in Gesäuse National Park (NP) based on broad basic research. Before detailing the endemics of this NP in the Northern Calcareous Alps, I will summarize the arachnological substance data of the Austrian endemics catalogue, provide some infor-

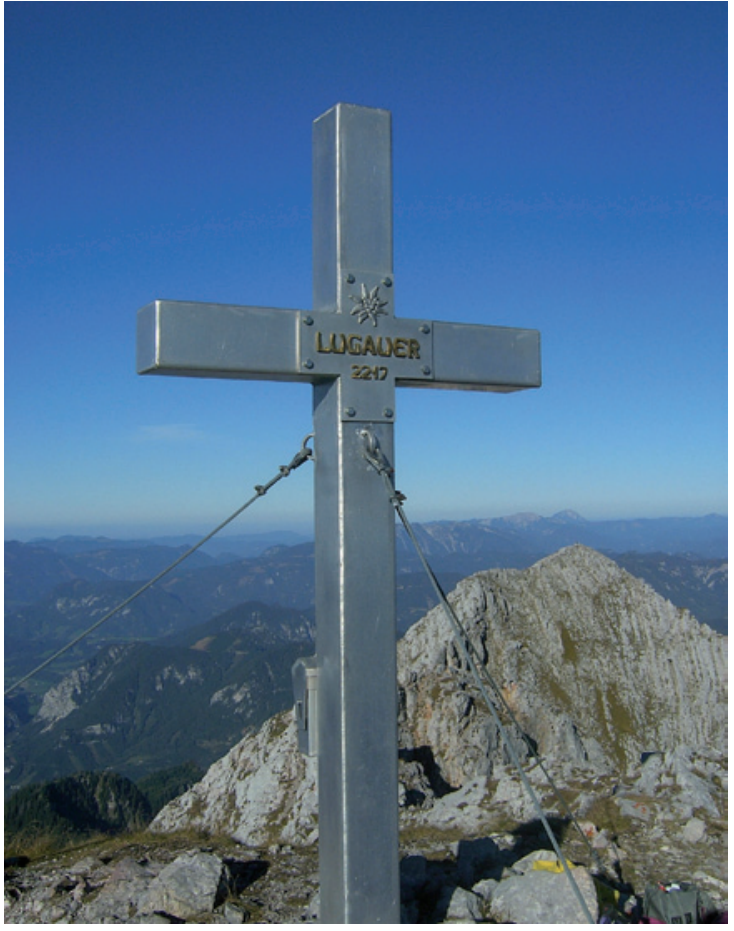

Figure 1 - Gesänse NP (2006). View from Mt. Lugauer $(2217 \mathrm{~m})$ to the northeast. The summit cross symbolizes the meaning of the high alpine zone for endemics. (C) Ch. Komposch, ÖKOTEAM 


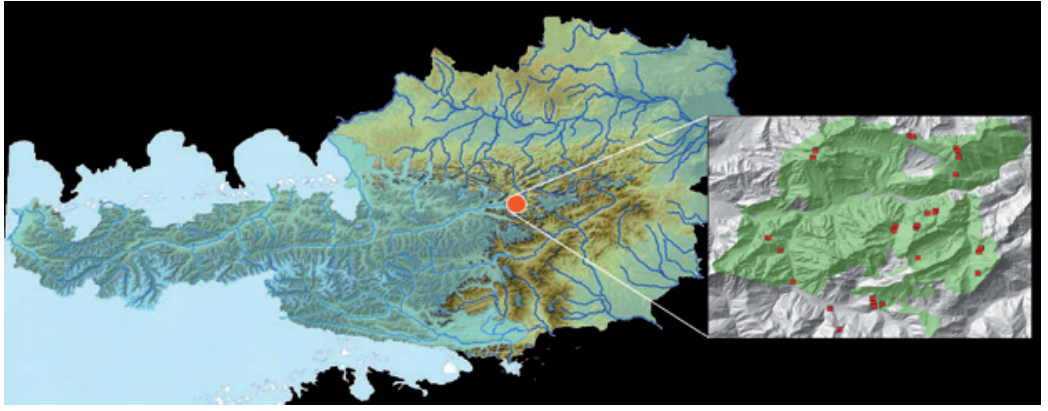

Figure 2 - The Eastern Alps at the maximum of glaciations during the last Ice Age (Würm): orography and political borders of Austria. The location of Gesäuse NP is marked, the insert shows its area with records of (sub)endemic spiders and harvestmen. (C) Ch. Komposch, ÖKOTEAM \&UBA Wien (modified after van Husen 1987, Rabitsch \& Essl 2009)

mation on the origin of Alpine endemics and present a short history of exploration in the Gesäuse region.

Endemic species of Austria

The Eastern Alps belong to the 30-35 million year old European Alp system and are largely contained within the national borders of Austria. Despite intensive research efforts of several Austrian zoologists in the past, like Rudolf Heberdey, Karl Holdhaus, Herbert Franz and Heinz Janetschek, or the German Gustaf De Lattin, as well as, more recently, renowned alpine arachnologists like Konrad Thaler and Jürgen Gruber, a comprehensive endemics catalogue of this country is still lacking. A recent study, coordinated by the Austrian Environmental Agency (Umweltbundesamt Wien) aimed to close this gap. The geographical localization, digitalization and management of all available data helps to draw up distribution maps and to identify for the first time centres and hotspots of faunal and floral endemism in the Eastern Alps. Included in this effort are taxa that are truly endemic to Austria as well as those whose distribution area lies primarily within its national borders (i.e. subendemic).

Recently, this comprehensive overview of plant, fungus and animal species with a range entirely (endemics) or predominantly (subendemics) within the political borders of Austria, was completed (Rabitsch \& Essl 2009), identifying a total of 748 (sub)endemic animal and plant species. Of these, the 548 animal species in Austria include 10 pseudoscorpion (Mahnert 2009), 11 harvestman (Komposch 2009a) and 46 spider species (Komposch 2009b). There are no real Austrian (sub) endemic species in the orders of scorpions (Komposch 2009c) and palpigrades (Christian 2009), whereas 10 oribatid mites (Schatz \& Schuster 2009) are classified as endemic and subendemic, many more oribatids as pseudoendemics.

\section{Origin of Alpine endemics}

If we want to understand the evolution of Alpine endemics we need to know the recent areas of the species (Thaler 1976), their habitats and ecology and have to look back into the past. Main reasons for the appearance of the recent fauna and the existence of these species distributed on a small scale in the Alps and Austria are:

The large-scale extinction of the past fauna of the Eastern Alps as a result of the last ice shields. Already De Lattin (1967), like other zoogeographers, points out that the geological event with the strongest influence on the holarctic faunas was the advent of the Pleistocene ice-ages. Holdhaus (1954) even writes about a rettungslose Vernichtung (desperate devastation) of the Alpine fauna by the glaciations.

The push exerted by the glaciations on the inhabitants of the Alps towards southern refugia (Brignoli 1983; Weiss \& Ferrand 2007), plus evolutionary processes and post-glacial short and long distance re-immigration (Holdhaus 1954; Janetschek 1956; Thaler 2003).

The survival in so-called massifs de refuge, i.e. unglaciated massifs at the periphery of the ice shields, in caves and - rarely - on inner-alpine nunataks (Holderegger \& Thiel-Egenter 2009). Nunataks are steep ice-free mountain peaks that stick out through the ice crust.

Due to the particular ways of glaciation, survival and migration processes in the Eastern Alps, the diversity of endemic and subendemic spiders and harvestmen shows a south/north and an east/west divide (cf. Muster 2001, 2002).

\section{History of the Gesäuse exploration}

The investigated area is Gesäuse NP $\left(47^{\circ} 30^{\prime}-38^{\prime} \mathrm{N}\right.$, $\left.14^{\circ} 31^{\prime}-44^{\prime} \mathrm{E}, 490-2369 \mathrm{~m}\right)$. The NP is located in the Ennstaler Alps, Northern Calcareous Alps in Styria, Austria. It is divided by the river Enns into a southern part with the peaks Reichenstein, Gr. Ödstein, Hochtor $(2369 \mathrm{~m})$, Planspitze, Hochzinödl, Stadelfeldschneid and Lugauer, and a northern part with Gr. Buchstein $(2224 \mathrm{~m})$ and Kl. Buchstein, Tieflimauer, Tamischbachturm and Almmauer. The Gesäuse is situated east of the towns of Admont and Liezen. The protection status of this area is quite young and dates from October 2002; despite its great vertical extension of 1880 metres, at just $111 \mathrm{~km}^{2}$ it is rather small.

The Gesäuse area can be regarded as historically quite well explored in arachnological and entomological terms. This exceptional situation is due to the fact that one of the world's most active and important collectors directed his special faunistic interest to "his" Gesäuse mountains. Herbert Franz lived in the village of Admont from 1939 to 1951 and mapped this area during those years systematically and exhaustively by means of a soil-sifter (after Reitter) and by collecting by hand. Hundreds of harvestman specimens were determined by P. Gunhold and some by C.Fr. Roewer and J. Hadži, the considerable yield of spiders by $\mathrm{H}$. Wiehle, F.Ch. Wang und A. Holm. These datasets have been published in Franz' north-eastern Alps monograph (Franz \& Gunhold 1954: Opiliones; Wiehle \& Franz 1954: Araneae). After a 50-year break, the ad- 
ministration of Gesäuse NP GmbH (Daniel Kreiner, Lisbeth Zechner, Werner Franek) started with systematic, intensive, sustained investigations of the spider and harvestman fauna among others (e.g. Komposch \& Holzinger 2005; Komposch et al. 2008; Ökoteam 2009).

\section{Material and methods}

The term endemism requires a clear definition in terms of exact geographic boundaries. This paper deals with species and subspecies whose range lies entirely (endemics) or predominantly (subendemics) within the political borders of Austria. Subendemics in this context are defined as taxa with more than $75 \%$ of their total range within the national territory (Rabitsch \& Essl 2009).

All available data on endemic and subendemic harvestmen and spiders have been collected, reviewed, attributed geographically, digitalized and stored in our ÖKOTEAM database. For Austria, a total of more than 2250 datasets were analysed (Araneae: 1050 , Opiliones: 1200). About 100 datasets each of spiders and harvestmen stem from the Gesäuse area, the implementation of about 200 datasets of (sub)endemic species for the NP area into the database is in progress. The distribution maps - showing the natural zones as well as the political borders of the federal states - have been printed by the Austrian Environmental Agency (UBA).

\section{Results and discussion}

Gesäuse NP harbours at least 26 harvestman species, 6 of them are subendemic to Austria. That means that a remarkable $55 \%$ of the nationwide Opiliones spectrum as well as (sub)endemics of this arachnid taxon occur in a small area covering just $0.13 \%$ of the national territory. As far as we know today, the spider fauna of Gesäuse NP currently numbers about 200 species, in reality there should be nearly twice as many. 12 of these currently known 200 spider species $(6 \%)$ are Austrian endemics and subendemics, i.e. $26 \%$ of the (sub)endemic spider fauna are living in our area of interest.

As expected, in Gesäuse NP as in the whole of the Eastern Alps, most of the endemic arachnid species occur from the nival down to the montane zone (Table 1): the sub-montane zone harbours just 1 harvestman and 3 spider species, the montane 5 and 8 , the subalpine 5 and 10 and the alpine zone 2 harvestman and 5 spider species. In the Gesäuse, the most important habitats for (sub)endemic harvestmen are rocks, rock debris and block fields as well as caves and crevices and near-natural woodlands. Spiders prefer rock debris and rocks, avalanche corridors, snow pockets, (sub)alpine meadows and gravelly riverbanks. In terms of conserving the habitat function for endemic species, the summits of the Ennstaler Alps, which rise to more than $2000 \mathrm{~m}$ altitude, are most important. 6 harvestman species (100\%) and 8 spider species (57\%)

Table 1 - List of Austrian endemic (E) and subendemic (S) harvestmen (Opiliones) and spider (Araneae) species in Gesäuse NP (Styria, Austria), related to the altitudinal zones of their main occurrence in the area (colline to nivale). RLA $=$ Red List of endangered harvestmen and spiders of Austria (Komposch 2009d, Komposch in press). Used endangerment categories: LC = Least Concern, $N T=$ Near Threatened, $V U=$ Vulnerable, $E N=$ Endangered, $C R=$ Critically Endangered .

\begin{tabular}{|c|c|c|c|c|c|c|c|c|c|c|}
\hline No & Family & Taxon & $E / S$ & RLA & $\stackrel{\stackrel{0}{\Xi}}{\overline{\bar{\delta}}}$ & 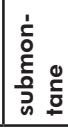 & 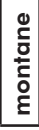 & 을 & 高 & $\bar{\delta}$ \\
\hline & & \multicolumn{9}{|l|}{ Opiliones (harvestmen) } \\
\hline 1 & Cladonychiidae & Holoscotolemon unicolor (Roewer, 1915) & S & EN & $x$ & $x$ & $x$ & & & \\
\hline 2 & Nemastomatidae & Mitostoma alpinum (Hadzi, 1931) & S & EN & & & & $x$ & $x$ & \\
\hline 3 & & Paranemastoma bicuspidatum (C.L. Koch, 1835) & S & EN & & & $x$ & $x$ & & \\
\hline 4 & Ischyropsalididae & Ischyropsalis kollari (C.L. Koch, 1839) & S & VU & $\mathrm{x}$ & & $x$ & $x$ & $x$ & \\
\hline 5 & Phalangiidae & Megabunus lesserti (Schenkel, 1927) & $\mathrm{S}$ & VU & & & $x$ & $x$ & & \\
\hline \multirow[t]{2}{*}{6} & Sclerosomatidae & Leiobunum subalpinum (Komposch, 1998) & S & VU & & & $x$ & $x$ & & \\
\hline & & \multicolumn{9}{|l|}{ Araneae (spiders) } \\
\hline 7 & Linyphiidae & Meioneta ressli (Wunderlich, 1973) & S & VU & & & & $x$ & & \\
\hline 8 & & Mughiphantes styriacus (Thaler, 1984) & E & CR & & & & & $x$ & \\
\hline 9 & & Mughiphantes variabilis (Kulczynski, 1887) & S & NT & & & & $x$ & $x$ & $x$ \\
\hline 10 & & Palliduphantes montanus (Kulczynski, 1898) & S & LC & & & $x$ & $x$ & & \\
\hline 11 & & Silometopus rosemariae (Wunderlich, 1969) & S & VU & & & & $x$ & $x$ & \\
\hline 12 & & Tenuiphantes jacksonoides (Van Helsdingen, 1977) & S & NT & & & $x$ & $x$ & $x$ & \\
\hline 13 & & Troglohyphantes noricus (Thaler \& Polenec, 1974) & S & VU & $x$ & $x$ & $x$ & & & \\
\hline 14 & & Troglohyphantes subalpinus (Thaler, 1967) & S & VU & & $x$ & $x$ & $x$ & & \\
\hline 15 & & Troglohyphantes thaleri (Miller \& Polenec, 1975) & S & VU & & $x$ & $x$ & $x$ & & \\
\hline 16 & Hahniidae & Cryphoeca lichenum lichenum (L. Koch, 1876) & S & NT & & & $x$ & $x$ & & \\
\hline 17 & Gnaphosidae & Zelotes zellensis (Grimm, 1982) & S & VU & & & $x$ & $x$ & & \\
\hline 18 & Thomisidae & Xysticus secendens (L. Koch, 1876) & S & VU & & & $x$ & $x$ & $x$ & \\
\hline
\end{tabular}




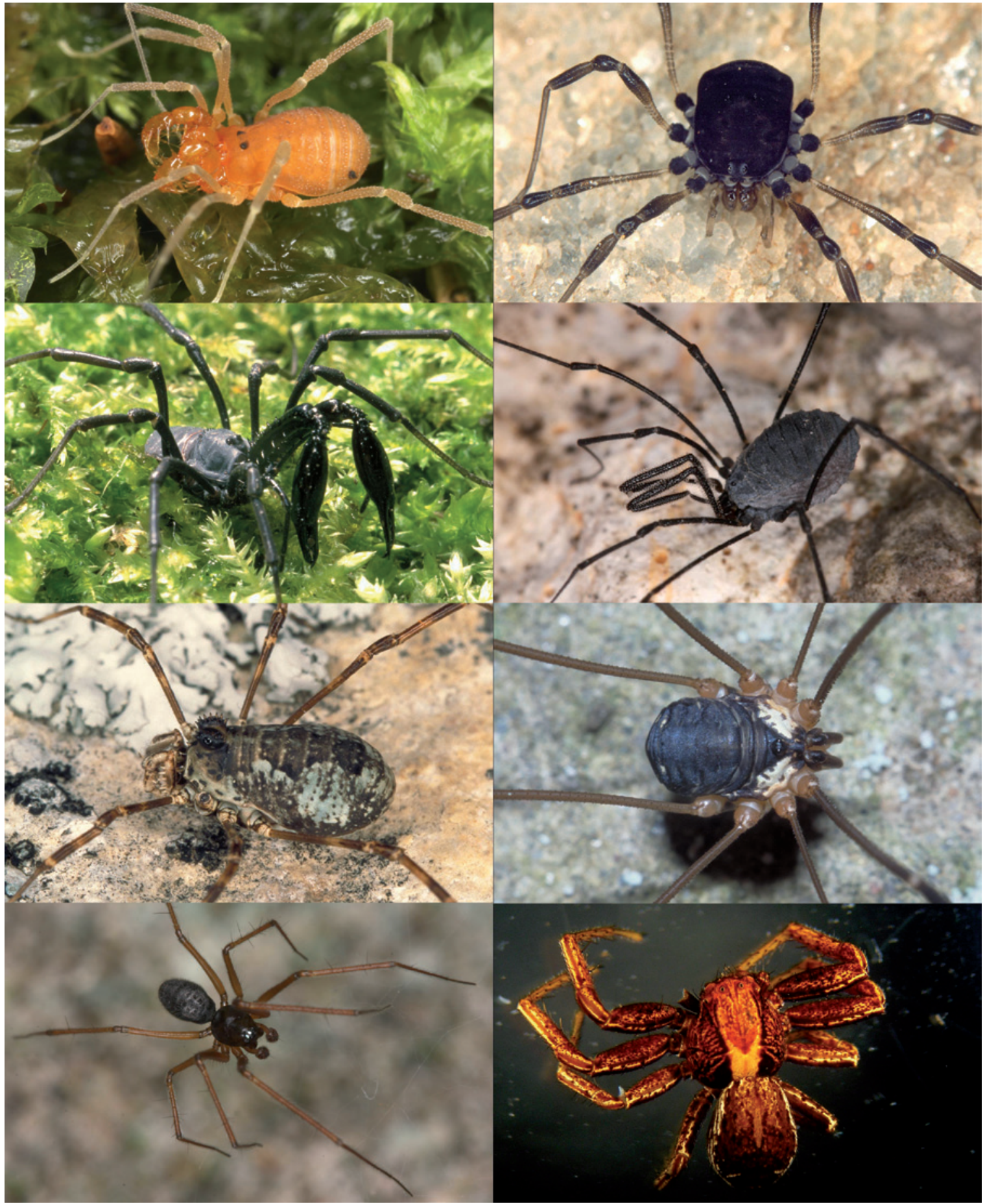

Figure 3-10 - Habitus of Austrian subendemic harvestmen and spiders recorded in Gesäuse NP. From left to right, from top to bottom: Opiliones: Holoscotolemon unicolor, Paranemastoma bicuspidatum, Ischyropsalis kollari, Mitostoma alpinum, Megabunus lesserti, Leiobunum subalpinum. Araneae: Mughiphantes variabilis, Xysticus secedens. (C) Ch. \& B. Komposch, ÖKOTE AM

of these subendemics and endemics are Critically Endangered up to Vulnerable, according to the current Red List for Austria (Komposch 2009d in press). A main threat to these cold-stenotopic arachnids, living as relicts from the last ice-age on the very top of these mountains, is climate warming and the impossibility of escaping to higher and colder habitats.

High absolute numbers and percentages of (sub) endemic harvestmen can be found within the soil- inhabiting families Cladonychiidae, Nemastomatidae and Ischyropsalididae. Two third of the (sub)endemic harvestman species belong to these soil-dwelling families. The laniator Holoscotolemon unicolor is the most striking harvestman in terms of colouring. It lives in deep leaf layers of near-natural beech forest and humid forest in canyons (Schluchtwälder). Surprisingly, the nemastomatid Paranemastoma bicuspidatum is also found here. The Gesäuse record of this hygrobiotic species 


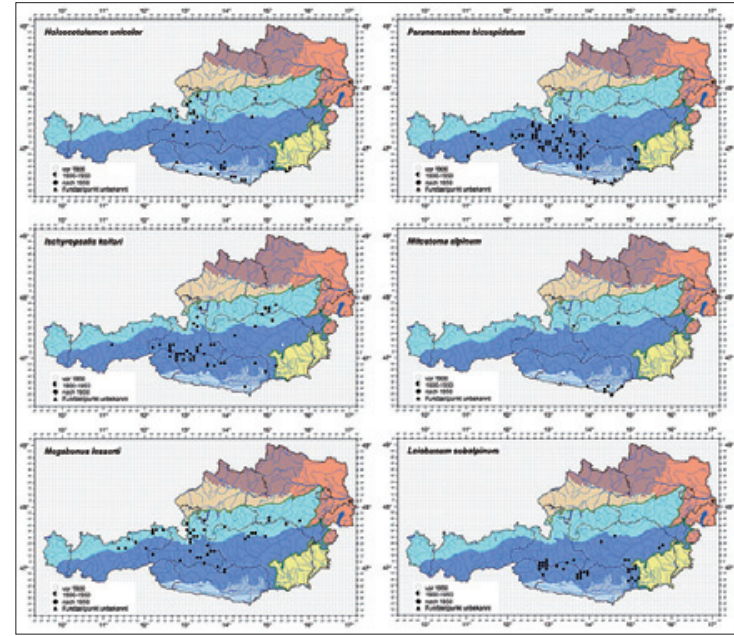

Figure 11-16 - Pattern of distribution of Austrian subendemic harvestmen (Opiliones) in Gesäuse NP: Holoscotolemon unicolor, Paranemastoma bicuspidatum, Ischyropsalis kollari, Mitostoma alpinum, Megabunus lesserti, Leiobunum subalpinum. (C) Ch. Komposch, ÖKOTEAM \& UBAWien

at the Johnsbach riverbank and at the Etzbach spring (Komposch et al. 2008) is a fair distance from the currently known eastern and north-eastern boundary of its area. The saxicolous sclerosomatid Leiobunum subalpinum, discovered and described little more than ten years ago, reaches the northern limit of its area in the Gesäuse Alps. As preliminary investigations in the genus Mitostoma have shown, Gesäuse NP may well yield taxonomic surprises in terms of discovering new species.

Three quarters of these special endemic and subendemic Gesäuse spiders belong to the linyphiids. Within this family, the two genera Lepthyphantes s. 1 . (Mughiphantes, Palliduphantes, Tenuiphantes) and Troglohyphantes make up more than three quarters of its (sub) endemics. A zoogeographic surprise is the recent find of Mughiphantes variabilis in this area (Komposch et al. 2008) for the Johnsbach site Langgriesgraben and Komposch \& Blick 2010 from the Steinkarhöhle in the northern parts of Mt. Stadelfeld. Until now, this species had been thought of as inhabiting only the more western parts of Austria (cf. Komposch 2009b). The current record of Zelotes zellensis in Gesäuse NP also far exceeds the known distribution in the Northern and Southern Calcareous Alps. The cave and crevices inhabiting species of the genus Troglohyphantes are represented by at least three species in the Gesäuse. The area is the centre of distribution for Troglohyphantes noricus and the northern boundary of T. thaleri; the situation is similar for Xysticus secendens.

The Southern Calcareous Alps with their highest peaks in the south-western parts (Mercantour NP and Alpi Marittime NP) are hotspots of endemic diversity, i.e. centres of arachnological and zoological diversity and endemism within the Alps (Maurer \& Thaler 1988). The number of endemic and subendemic arachnids

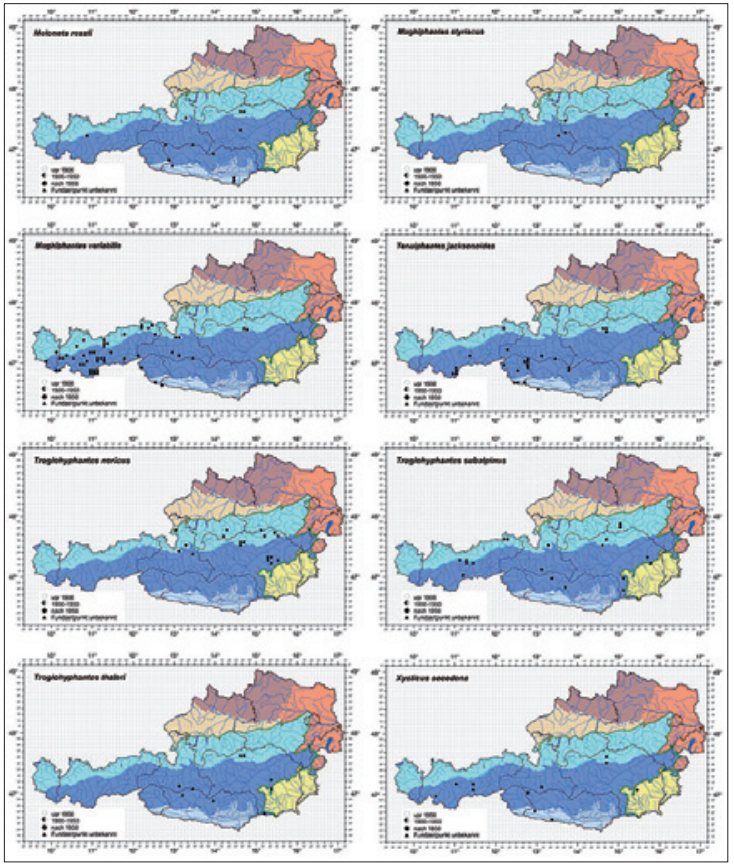

Figure 17-24 - Pattern of distribution of Austrian endemic and subendemic spiders (Araneae) in Gesäuse NP: Meioneta ressli, Mughiphantes styriacus, M. variabilis, Tenuiphantes jacksonoides, Troglohyphantes noricus, T. subalpinus, T. thaleri and Xysticus secedens. (C) Ch. Komposch, ÖKOTEAM \& UBAWien

of Austria is remarkably high and varies greatly across the nine federal provinces. The mountainous federal provinces of Styria, Carinthia, Tyrol and Salzburg are rich in endemic spiders and harvestmen. Following the definitions of subendemism of Rabitsch \& Essl (2009), highest arachnid species numbers are found in the Central Alps (Hohe Tauern NP, Gurktaler Alps and Koralpe summit, but also the Ötztaler and Stubaier Alps), the north-eastern Calcareous Alps (Ennstaler Alps: Gesäuse NP) and in particular in the Southern Alps (Karawanken and Steiner Alps) with their massifs de refuge marking the margin of the Würm ice shields. For animals, a maximum of 46 endemic taxa was found in a grid cell in Gesäuse NP, the Hochobir in the Karawanken came second with 41 endemic taxa. Regions outside the Alps are poor in endemics.

\section{Conclusions - or how to preserve the real treasures of the Austrian fauna}

The results of a decade of research in the Gesäuse provide a valuable basis for zoogeographical inferences involving glacial refugia and postglacial recolonization of the fauna of the Alps in arachnological terms as well as for conservation planning in Austria. It highlights the vital role of Gesäuse NP for preserving an unique bouquet of Austrian endemic and subendemic arachnids in addition to highly diverse coenoses. Looking at the cumulative distribution map of Austria (Figure 25), the great diversity of endemic spiders and harvestmen in the Karawanken and at the 


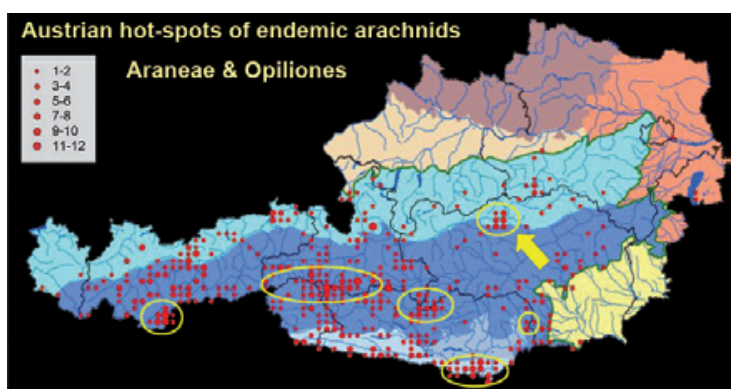

Figure 25 - Cumulative distribution map showing all endemic and subendemic spiders and harvestmen in Austria (modified after Komposch 2009b). The most important hotspots of endemism are ringed, Gesäuse NP is marked with an arrow. (C) Ch. Komposch, ÖKOTEAM \& UBA

Koralpe (both Carinthia) has confirmed expectations but greatly exceeded them for Gesäuse NP - apart from the richness of the Gurktal Alps. Further faunistic and taxonomic work in these areas should yield new and undescribed species.

The need for action is great, as is the time pressure due to habitat destruction, climate warming and the loss of experts in arachnids, millipedes, gastropods and insects. For the long-term preservation of Gesäuse NP the following suggested five steps need to be taken urgently:

Politics: A guarantee for the long-term protection of the young Gesäuse NP is a prerequisite. Given the fact that this small area bears a quarter of the Austrian (sub)endemic spider fauna, more than half of (sub)endemic harvestmen and is the endemic hotspot in Austria, recurring political debates about a dissolution of this national park are highly irresponsible.

Basic research: Detailed mapping and documentation of arachnids and other invertebrates in Gesäuse NP is indispensible. All important habitat types must be investigated. The arachnid fauna of caves and natural forests, for instance, is still almost completely unknown. The large-scale rocky habitats

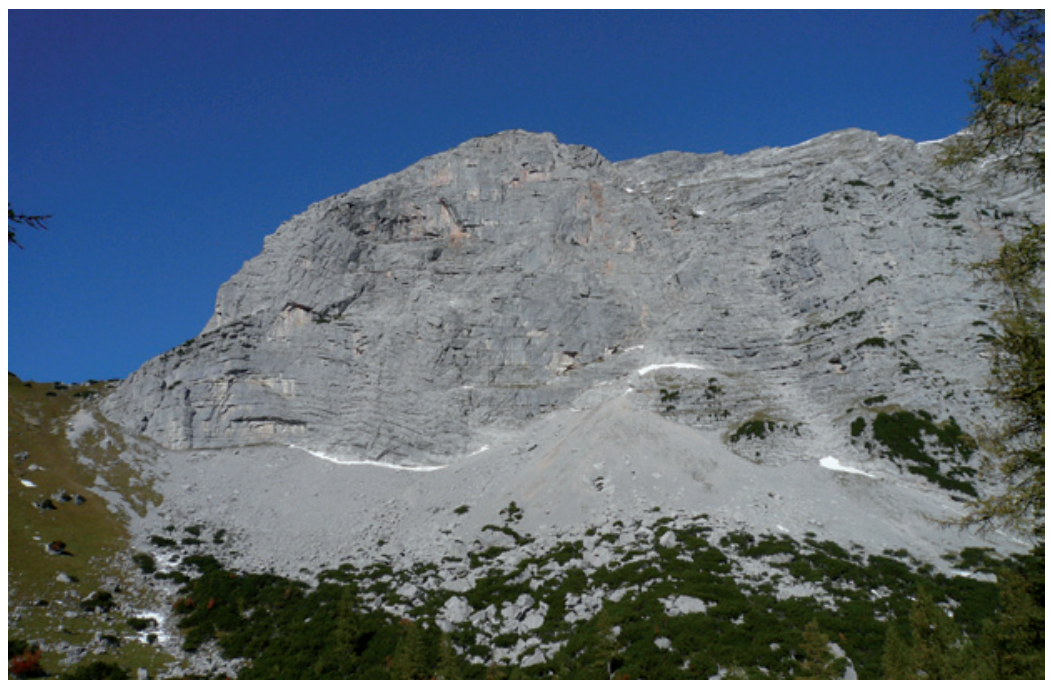

Figure 26 - Gesäuse NP (2007). Mt. Hochzinödl (2191 m) seen from the Sulzkearalm. (C) Ch. Komposch, ÖKOTEAM need further research from the Hochtor peak down to the gravel banks of the river Enns. A detailed cartographic description of the distribution of endangered species is required, especially for the subendemic and endemic taxa. Taxonomic analyses need to start, combining both morphological and genetic characters. We assume that there is twice the number of spider species in the NP area than are currently known. Preliminary results of taxonomic investigations suggest that several unknown harvestman, spider and pseudoscorpion species are living there.

Protection measures: The endemic and subendemic species depend on protection enshrined in federal conservation law (Artenschutzverordnung des Landes Steiermark). This is the only way to include and consider these highly endangered species in environmental impact studies (UVEs, NVPs). Moreover, these exclusive and unique taxa must be integrated into protection and wildlife conservation programmes. A next step is to check and assess the compatibility of current human activities and land uses inside the NP, such as forestry, gravel mining, hunting, alpine farming and tourism, with habitat protection.

A difficult but essential question is: why are the boundaries of Gesäuse NP so artificial, disregarding natural zoning arguments entirely? The arbitrarily drawn boundaries exclude important centres of diversity and further hotspots of endemics, such as the whole of the Haller Mauern and large parts of the mountains Reichenstein, Hochtor, Lugauer, Tamischbachturm, the Buchstein massif etc. Protected areas in Austria do not cover the distribution of endemics very well. So far, not one of the Austrian conservation areas or NPs has been established around a place of high or even outstanding diversity of endemic invertebrates. Not more than 10 of the 16 quadrants with the highest numbers of endemic animals in Austria are included in effective conservation areas.

University training: It should be remembered that during the last century Austrian zoogeographers and biologists played a key role in solving problems of and understanding the post-glacial recolonization and evolution of Alpine endemic species. Today, most Austrian and Central European universities present a dismal situation, denying and even condemning organismic biology, faunistics, zoogeography and taxonomy (Kropf 1996; Klausnitzer 2007, see also declaration elsewhere in this issue). We are well on the way to losing "real" biologists and specialists able to correctly identify a species. At universities and museums, students should be encouraged and funded to work on faunistic and zoogeographical topics, taxonomical courses must be offered regularly and jobs created for organismic biologists and taxonomists. Many specialists today are found among self-employed biologists and non- 
professionals - they deserve logistic support and funding for biodiversity research.

Public relations: The special case of non-iconic animals, the need for attention, research and protection must be imparted to the public. It is not only birds, mammals and fish that need protection. The "pets of nature conservation", such as vulture, wolf, capercaillie and brown bear exist throughout Europe. We Austrians must focus on those nuggets of biodiversity located exclusively in our country, or no one else will. Despite all the benefits of the Natura 2000 network of the European Union - Brussels does not care about the endemics of the Alps. It should be emphasized and remembered that Gesäuse NP - like the Hohe Tauern, Nockberge, Kalkalpen NPs and so on - derives its uniqueness form its geomorphological character and its endemic spider, harvestman, pseudoscorpion, insect, gastropod and millipede fauna.

Our politicians must secure protected area status of Gesäuse NP for the longer term to provide an adequate framework for successful long-term planning. The technical and scientific administration of the NP should continue their policies as in recent years. Within and outside Gesäuse NP conservation efforts must focus on these unique tesserae of our Alpine fauna!

\section{Acknowledgements}

I am deeply grateful to Konrad Thaler (†), Jürgen Gruber and Albert Ausobsky for arachnological data and general support. My thanks also go to Theo Blick, Thomas Frieß, Werner Holzinger, Jördis Kahapka, Barbara Knoflach, Brigitte Komposch, Jochen Martens, Christoph Muster, Tone and Ljuba Novak, Wolfgang Paill, Wolfgang Rabitsch, Axel Schönhofer and Reinhart Schuster for data, help with fieldwork and discussions. Two anonymous reviewers helped with constructive and welcome comments - many thanks for taking the trouble! Last but not least I would like to thank Daniel Kreiner, Lisbeth Zechner, Werner Franek and Kristina Bauch for advancing the recent investigations and publications. I am deeply grateful to Brigitte Scott and Valerie Braun for linguistic help and editorial work. Support for the congress participation and presentation of Austrian endemics in Alexandroupolis 2009 came from the Österreichische Forschungsgemeinschaft and the Styrian government.

\section{References}

Brignoli, P.M. 1983. Dispersion, Dispersal and Spiders (Arachnida: Araneae). Verbandlungen des Naturwissenschaftlichen Vereins in Hamburg NF 26: 181-186.

Christian, E. 2009. Palpigradi (Tasterläufer). In: Rabitsch, W. \& F. Essl (Red.), Endemiten. Kostbarkeiten in Österreichs Tier- und Pflanzenwelt: 406-407. Klagenfurt \& Wien.
Franz, H. \& P. Gunhold 1954. 19. Ordnung Opiliones. In: Franz, H., Die Nordostalpen im Spiegel ibrer Landtierwelt. Eine Gebietsmonographie: 461-472.

Holderegger, R. \& C. Thiel-Egenter 2009. A discussion of different types of glacial refugia used in mountain biogeography and phylogeography. Journal of Biogeography 36: 476-480.

Husen, D. van 1987. Die Ostalpen in den Eiszeiten. Populärwissenschaftliche Veröffentlichungen der Geologischen Bundesanstalt. Wien.

De Lattin, G. 1967. Grundriß der Zoogeographie. Stuttgart.

Klausnitzer, B. 2007. Faunistik als Zukunftswissenschaft. Entomologische Zeitschrift 117: 3-6.

Holdhaus. K. 1954. Die Spuren der Eiszeit in der Tierwelt Europas. Abhandlungen der zoologisch-botanischen Gesellschaft in Wien. 18.

Janetschek, H. 1956. Das Problem der inneralpinen Eiszeitüberdauerung durch Tiere (Ein Beitrag zur Geschichte der Nivalfauna). Österreichische Zoologische Zeitschrift 6: 421-506.

Komposch, Ch. 2009a. Weberknechte (Opiliones). In: Rabitsch, W. \& F. Essl (Red.), Endemiten. Kostbarkeiten in Österreichs Tier- und Pflanzenwelt: 476-496. Klagenfurt \& Wien.

Komposch, Ch. 2009b. Spinnen (Araneae). In: Rabitsch, W. \& F. Essl (Red.), Endemiten. Kostbarkeiten in Österreichs Tier- und Pflanzenwelt. Ökologie: 408-463. Klagenfurt \& Wien.

Komposch, Ch. 2009c. Skorpione (Scorpiones). In: Rabitsch, W \& F. Essl (Red.), Endemiten. Kostbarkeiten in Österreichs Tier- und Pflanzenwelt: 496-500. Klagenfurt \& Wien.

Komposch, Ch. 2009d. Rote Liste der Weberknechte (Opiliones) Österreichs. In: Zulka, P. (Red.), Rote Listen gefährdeter Tiere Österreichs. Checklisten, Gefährdungsanalysen, Handlungsbedarf. Grüne Reibe des Lebensministeriums 14 (3): 397-483.

Komposch, Ch. in press. Rote Liste der Spinnen Österreichs (Arachnida: Araneae). In: Zulka, P. (Red.),

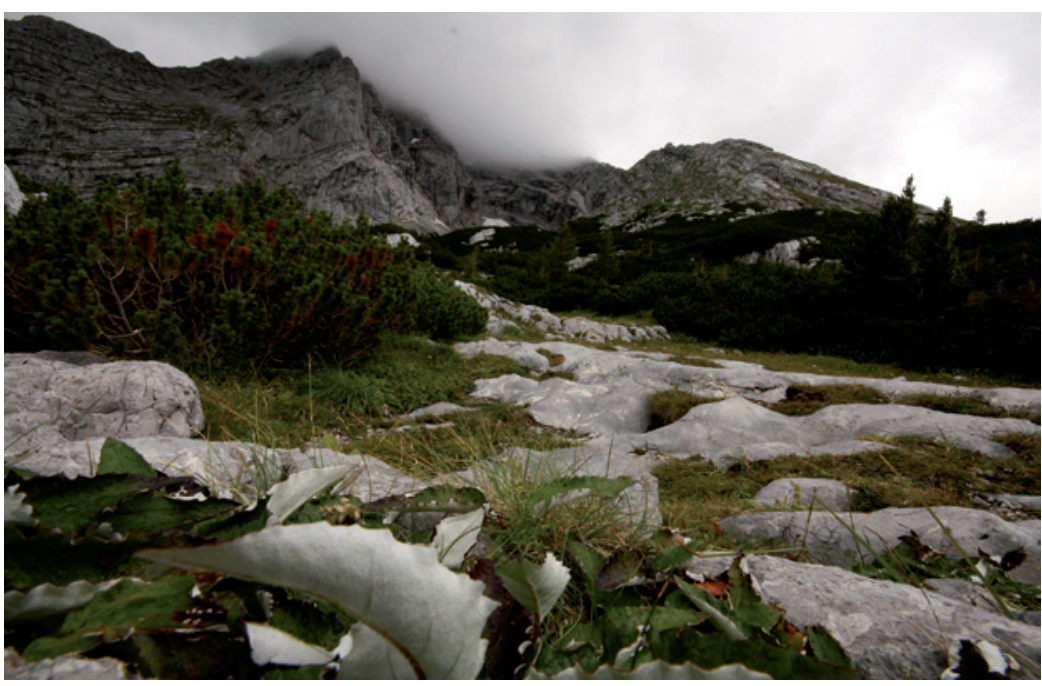

Figure 27 - Gesäuse NP (2009). Mt Hochtor, seen from the Hesshütte area. (C) Ch. Komposch, ÖKOTEAM 
Rote Listen gefährdeter Tiere Österreichs. Checklisten, Gefährdungsanalysen, Handlungsbedarf. Grüne Reibe des Lebensministeriums 14 (4).

Komposch, Ch. \& Th. Blick 2010. Hesshütte, Hochzinödl und Hochtor - Herausforderung Spinnenkartierung (Arachnida: Araneae) am 11. GEO-Tag der Artenvielfalt. In: Kreiner, D. \& L. Zechner (Red.), GEO-Tag der Artenvielfalt 2009. Schriften des Nationalparks Gesäuse 5: 90-104.

Komposch, Ch. \& W. Holzinger 2005. Nature conservation evaluation of alpine pastures in the Gesäuse National Park (Styria, Austria) by means of the bioindicators spiders, leaf- and planthoppers (Arachnida: Araneae; Insecta: Auchenorrhyncha). Conference Volume of the 3rd Symposion of the Hohe Tauern National Park for Research in Protected Areas. September 15th to 17th, 2005, Castle of Kaprun: 117-120.

Komposch, Ch., Th. Blick, P. Horak, K. Brandl, A. Platz \& B. Komposch 2008. Arachnidenreich Gesäuse - Spinnen und Weberknechte. In: Kreiner, D. \& L. Zechner (Red.), Artenreich Gesäuse (9. GEO-Tag der Artenvielfalt im Johnsbachtal und an der Enns im Nationalpark Gesäuse 2007). Schriften des Nationalparks Gesäuse 3: 109-125.

Kropf, Ch. 1996. Biosystematische Forschung am Museum - eine Standortbestimmung. Jabrbuch des Naturbistorischen Museums Bern 12: 137-159.

Mahnert, V. 2009. Pseudoscorpiones (Pseudoskorpione). In: Rabitsch, W. \& F. Essl (Red.), Endemiten. Kostbarkeiten in Österreichs Tier- und Pflanzenwelt: 501-508. Klagenfurt \& Wien.

Maurer, R. \& K. Thaler 1988. Über bemerkenswerte Spinnen des Parc National du Mercantour (F) und seiner Umgebung (Arachnida: Araneae). Revue suisse de Zoologie 95: 329-352.

Muster, C. 2001. Biogeographie von Spinnentieren der mittleren Nordalpen (Arachnida: Araneae, Opiliones, Pseudoscorpiones). Verbandlungen des Naturwissenschaftlichen Vereins in Hamburg 39: 5-196.

Muster, C. 2002. Substitution patterns in congeneric arachnid species in the northern Alps. Diversity and Distribution 8: 107-121.

Ökoteam 2009. Tierische Endemiten im Nationalpark Gesäuse. Auftreten ausgewählter endemischer und subendemischer Spinnentiere und Insekten. Unveröffentlichter Projektendbericht im Auftrag der Nationalpark-Gesäuse$\mathrm{GmbH}$.

Rabitsch, W. \& F. Essl (Red.) 2009. Endemiten - Kostbarkeiten in Österreichs Pflanzen- und Tierwelt. Klagenfurt \& Wien.

Schatz, H. \& R. Schuster 2009. Oribatida (Hornmilben). In: Rabitsch, W. \& F. Essl (Red.), Endemiten. Kostbarkeiten in Österreichs Tier- und Pflanzenwelt: 464 475. Klagenfurt \& Wien.

Thaler, K. 1976. Endemiten und arktoalpine Arten in der Spinnenfauna der Ostalpen (Arachnida: Araneae). Entomologica Germanica 3: 135-141.

Thaler, K. 2003. The diversity of high altitude arachnids (Araneae, Opiliones, Pseudoscorpiones) in the Alps. In: Nagy, L., G. Grabherr, Ch. Körner \& D. B. A. Thompson (eds.), Alpine Biodiversity in Europe. Ecological Studies 167: 281-296.

Weiss, S. \& N. Ferrand 2007. Phylogeography of southern European refugia: evolutionary perspectives on the origins and conservation of European biodiversity.

Wiehle, H. \& H. Franz 1954. 20. Ordnung: Araneae. In: Franz, H., Die Nordostalpen im Spiegel ihrer Landtierwelt: 473-556.

\section{Author}

\section{Christian Komposch}

Director of the company ÖKOTEAM, private researcher and lecturer at the University of Graz and for the M.Sc. programme Management of Protected Areas at the University of Klagenfurt. Main fields of research include arachnid taxonomy and ecology, endemism, red lists and nature conservation evaluations. Has been mapping the Gesäuse from the Enns river up to the high-alpine zone of the Lugauer, Hochzinödl etc. since 1992.

ÖKOTEAM - Institute for Animal Ecology and Landscape Planning, Bergmanngasse 22, 8010 Graz, Austria.

c.komposch@oekoteam.at www.oekoteam.at 